The Research Journal of the Costume Culture

[Original Article]

Received December 28, 2016

Revised June 24, 2017

Accepted June 26, 2017

${ }^{\dagger}$ Corresponding author

(jschun@yonsei.ac.kr)

ORCID

Jeehye Park

http://orcid.org/0000-0002-3080-0960

Jongsuk Chun

http://orcid.org/0000-0002-0387-709x
pISSN 1226-0401

RJCC Vol.25, No.3, pp.391-404, June 2017

https://doi.org/10.7741/rjcc. 2017.25.3.391

\title{
Consumer's demands on functional design for sports climbing pants and product developments
}

\author{
Jeehye Park and Jongsuk Chun ${ }^{\dagger}$ \\ Dept. of Clothing \& Textiles, Yonsei University, Korea

\section{스포츠 클라이밍 팬츠의 기능적 디자인에 대한 소비자 수요 특성과 상품 개발} \\ 박 지 혜·천 종 숙 ${ }^{\dagger}$ \\ 연세대학교 의류환경학과
}

\begin{abstract}
The purpose of this study was to identify the consumers' demands on functional design of sports climbing pants. Data were collected through a field survey. 82 male and 70 female amateur sports climbers in Seoul participated. The questionnaires measured aspects of functional design in sports climbing pants, specifically motion adaptability, comfort and aesthetic value of the climbing pants. The results of this study show that comfort during climbing postures was the most important value of the climbing pants. The subjects sought motion adaptability at the hip, crotch, thigh and knee. The preferred style and degree of fit of climbing pants were differed according to gender. Men preferred loose or semi tight fit style climbing pants but women preferred the leggings style of the sport pants. The soft touch seam line and body shaping function were also important for women. The type of pants preferred for sports climbing also differed by the climbing experience period. Men began to wear the outdoor mountaineering style pants when they had experienced sports climbing for 6 months and to wear the climbing expert style pants when they had experienced sports climbing for a year. Most women wore leggings style sports pants from the beginner stage. This study also analyzed Korean market trend in 2016 2017 F/W for sports climbing pants design. The men's pants were more likely to be designed to improve mobility compared to the women's pants, even though the aesthetic value of the sports climbing pants was important for women.
\end{abstract}

Keywords: sports climbing(스포츠 클라이밍), pants(팬츠), functional design(기능적 디자인)

\section{Introduction}

스포츠 클라이밍은 암벽등반의 장점을 부각시켜 개발된 스포츠로, 인공 암벽에 부착된 홀드를 쥐거나 딛고 다양한 난이도로 구성된 루트를 오르는 익스트림 스포 츠이다(Jeong \& Kim, 2014). 스포츠 클라이밍은 1987년 국제산악연맹의 국제등 
반경기위원회(CICE: Comite International des Competitions'd Escalade) 발족을 계기로 시작되어 '청소년월 드챔피언십'과 ‘유럽 대륙 챔피언 십, '아시아 대륙 챔 피언 십’ 등 공식적인 국제적 경기가 개최되면서 전 문적인 스포츠 종목으로 인정되었고(Son, 2003), 2020 년 올림픽부터 정식 경기 종목으로 채택되었다(Lee, 2016).

스포츠 클라이밍 활동에 정기적으로 참여하는 인 구는 세계적으로 빠르게 증가하고 있다(IFSC: International Federation of Sport Climbing, 2017). 미국의 경우, 2015년 전체 인구의 $1.6 \%$ 가 스포츠 클라이밍 에 참여하였고(Outdoor foundation, 2016), 국내에서 도 1990년대 이후 스포츠 클라이밍 참여인구가 꾸준 히 증가하고 있다. 국내에서 스포츠 클라이밍에 대한 관심이 증가하는 이유는 대한민국 선수들이 세계 선 수권 대회에서 우수한 성적을 거둔 영향이기도 하다 (Kim, 2016). 스포츠 클라이밍 참여 인구의 증가에 따라 전국적으로 설치된 인공암벽의 수는 약 200 여개 로 증가하였으며(Park et al., 2015), 이제 스포츠 클라 이밍은 생활 스포츠로 자리잡았다고 평가되고 있다 (Jeong \& Kim, 2014; Kim, Song, Ko, \& Park, 2015). 스포츠 클라이밍과 관련된 연구도 활발하게 수행 되고 있다. 선행연구들은 주로 스포츠 클라이밍이 인 체에 미치는 신체적, 심리적 영향을 분석하였다. 체육 학 분야 연구자들은 스포츠 클라이밍 활동시에 인체 근육이 지속적 또는 간헐적으로 수축과 이완을 반복 하는 것이 건강과 근력 증가에 미치는 영향 등을 연 구하였다(Watts, Newbury, \& Sulentic, 1996; Sheel, 2004). 스포츠 클라이밍이 건강에 미치는 영향을 연 구한 선행연구(Son, Kang, Jung, \& Lee, 2013a)는 스 포츠 클라이밍 운동이 체지방과 허리 및 엉덩이둘레 치수의 감소와 인슐린 저항성을 개선하는 효과가 있 다고 주장하였다. 이외에도 선행연구자들은 스포츠 클라이밍 운동이 유산소 운동효과(Mermier, Janot, Parker, \& Swan, 2000)와 혈중 젖산농도 감소효과 (Kim \& Kim, 2003), 심폐기능 향상효과(Kim, Lee, $\mathrm{Kim}, \mathrm{Kim}, \& \mathrm{Lim}, 2008)$ 등이 있다고 주장하였다. 이 와 같은 건강 개선효과 외에도 스포츠 클라이밍을 규 칙적으로 수행할 경우, 낙상 예방 효과도 기대할 수 있다(Lee, Lee, \& Kang, 2013; Son, Kang, Jung, \& Lee, 2013b).
운동 시 발생하는 신체 부상 가능성 측면에서는 실 외에서 이루어지는 알파인 암벽등반이 부상 위험도 가 높은 반면, 스포츠 클라이밍은 안전 설비를 갖춘 실내 인공 암장에서 활동하므로 부상가능성이 낮다 는 장점이 있다(Neuhof, Hennig, Schoffl, \& Schoffl, 2011; Schoffl, Morrison, Schwarz, Schoffl, \& Kupper, 2010; Wright, Royle, \& Marshall, 2001). 그러나 안전 설비의 설치에 따른 부상예방의 장점은 스포츠 클라 이머들이 극단적인 운동동작을 과도하게 반복하는 역효과를 유발할 수 있다(Schoffl \& Winkelmann, 1999). 따라서 스포츠 클라이밍 운동시 부상을 예방하기 위 한 방안의 마련과 사전교육이 중요하다(Lee, Cho, \& Park, 2014).

이러한 스포츠 클라이머들의 안전한 스포츠 활동을 지원하기 위하여 최근에는 ICT 기술을 기반으로 개인 의 운동 능력을 맞춤형으로 훈련시키는 프로그램도 개발되고 있으며, 증강현실을 기반으로 인공 암벽에 캐릭터 애니메이션을 투사하는 훈련 시스템도 개발되 었다(Kim et al., 2015; Lee, Heo, Cha, \& Kim, 2016).

클라이밍용 스포츠웨어의 기능성 요소에 대한 수 요조사 연구들은 스포츠 클라이밍용 의류가 기후요 소를 주로 고려하여 제작하는 암벽등반용 의류와는 다른 기능적 디자인을 필요로 한다고 하였으며, 여성 과 남성의 수요특성도 다르다고 하였다(Johnston \& Koo, 2016; Jung \& Chun, 2013). 또한 클라이밍 동작 시의 족저압력 분석을 통해 발의 부하 감소와 피로 경감 효과를 추구하는 스포츠 클라이밍화를 개발하 기도 하였다(Park et al., 2015). 이러한 연구 결과들은 스포츠 클라이밍용 의류 개발 시 착용 대상자의 운동 수요 특성을 반영하여야 함을 시사한다.

\section{Theoretical Background}

\section{Characteristics of sports climbing}

스포츠 클라이밍은 산악 암벽등반에서 발생하는 부 상위험 가능성을 낮추어 스포츠화한 것으로 실내에 설치된 인공 암벽을 등반하는 익스트림 스포츠이다 (Son, 2007). 스포츠 클라이밍의 세부적 경기 종목은 난이도경기와 속도경기, 볼더링경기 세 가지로 구분 된다. 난이도경기는 제한 시간 내에 경기자가 도달하 는 위치의 높이를 겨루는 경기이며, 속도경기는 정해 
진 루트를 완등하는 데 소요되는 시간을 겨루는 경기 이다. 볼더링경기는 로프를 사용하지 않는 조건으로 최대 12 개의 기술 등반 과제를 수행하는 경기이며, 격렬한 몸놀림과 현란한 기술들로 인해 높은 인기를 보이고 있다(Son, 2003; Sung, 2009).

스포츠 클라이밍에서는 경사진 암벽 위에 발을 안 정적으로 위치시킬 지점을 확보하기 위해 다양한 다 이나믹한 자세를 취하게 된다. 따라서 스포츠 클라이 밍 운동시에는 고관절을 매우 크게 굽히거나 벌리거 나 회전시키는 자세와 무릎관절을 굽히는 자세 등 신 체 동작범위(ROM, range of motion)가 극단적으로 큰 자세가 나타나기도 한다(Jung, 2013). 대표적인 클 라이밍 자세로는 어깨 높이 이상의 높은 홀드에 먼저 발을 착지시킨 후, 체중을 위로 끌어올려 경사면을 오 르는 후킹 자세(hooking), 두 다리를 넓게 벌려 체중 을 안정적으로 분산시키면서 수직벽을 오르는 스테 밍 자세(stemming), 한쪽 다리에 체중을 실은 상태에 서 다른 쪽 발을 허리높이 이상의 발 홀드에 올려 착 지시킨 후, 몸을 위로 끌어올려 수직벽을 오르는 하이 스텝 자세(high step)가 있다. 이외에도 좌우 양쪽 고 관절과 무릎관절을 동시에 최대한 굴곡시켜 쭈그리 고 앉는 몽키 행 자세(monkey hang)가 있다(Fig. 1). 이처럼 스포츠 클라이밍에서 자주 사용되는 동작들 은 고관절과 무릎관절의 내전이나 외전, 굴곡과 신전 범위가 크므로 이러한 동작을 수행하는데 불편함이 없는 스포츠 클라이밍 전용 하의 개발이 필요하다.

\section{Demands for functional design}

클라이밍용 스포츠웨어에 대한 수요를 다양한 측 면에서 조사한 선행연구들은 클라이밍 수행 시 인체를
보호하고, 쾌적한 상태를 유지하기 위해서는 기능적 인 디자인 개발이 필요하다고 주장하였다. 예를 들어 클라이밍용 셔츠는 가슴, 허리, 어깨 부위의 밀착성을 강화하고, 목과 겨드랑이 부위의 압박은 경감시키는 디자인 요소가 필요하였으며(Seo \& Chun, 2014), 암 벽 등반과 빙벽 등반 전문가용 클라이밍 팬츠의 소재 는 하지 관절의 가동범위를 확보하고, 에너지 소모가 경감되도록 하는 기능을 제공하는 신축성과 경량성 이 우수한 소재를 사용할 것을 제안하였다(Jung \& Chun, 2013). 또한 선행연구들은 클라이밍용 스포츠 웨어의 기능성에 대한 수요에 남녀의 성별 차이가 있 다고 주장하였다. 남성들이 무릎 샅, 엉덩이부위의 활 동기능성에 높은 관심을 보인 반면, 여성들은 신체 노출에 따른 수치심을 예방할 수 있는 기능을 중요시 한다고 하였다. 또한 미국 여성 암벽 등반가들을 대 상으로 암벽등반용 의류의 수요 특성과 디자인 선호 경향을 조사한 Johnston and $\mathrm{Koo}(2016)$ 는 여성들이 클라이밍용 의류의 맞음새(fit)와 색상, 내구성에 대하 여 불만족이 높다고 하였다. 구체적으로는 클라이밍 시 바지의 솔기가 터지거나 찢어지는 경우에 대해 불 만족하였고, 클라이밍 시 바지의 무릎, 엉덩이, 샅부 위가 불편한 것에 대해서도 불만족이 높았다.

그러나 산악지역에서 수행하는 산악 등반과는 다 르게 스포츠 클라이밍은 실내에서 이루어지는 운동 이므로 실내 암벽등반용 팬츠의 디자인에 대한 수요는 산악 등반용 스포츠웨어와 차별하여 파악하여야 한 다. 따라서 본 연구는 남녀 스포츠 클라이머들을 대 상으로 스포츠 클라이밍용 팬츠에 대한 착용실태와 기능성 디자인 수요를 조사하였고, 국내 시장의 클라 이밍용 팬츠 상품 개발 특성을 조사하였다.

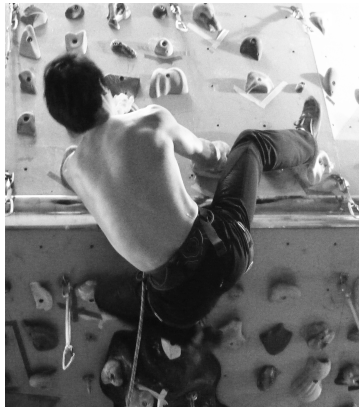

(a) Hooking

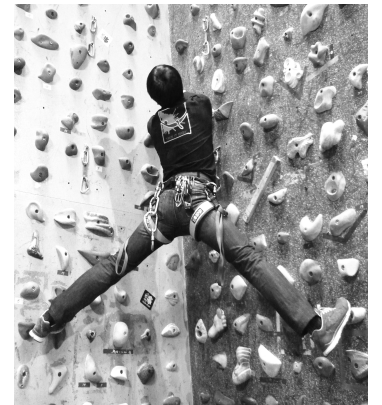

(b) Stemming

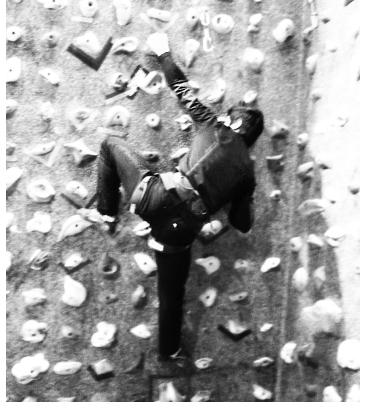

(c) High step

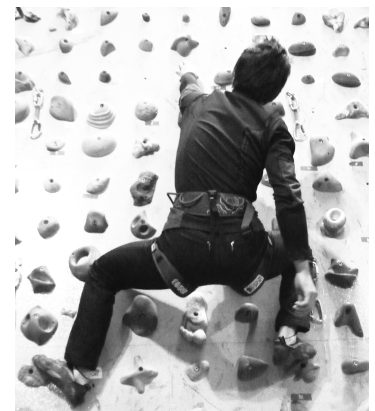

(d) Monkey hang

$<$ Fig. 1> Extreme motion of lower limb during sports climbing 


\section{Research Methods}

\section{Design demands on sport climbing pants}

\section{1) Data collection}

스포츠 클라이밍 팬츠의 기능적 디자인에 대한 수 요와 착용 실태 조사는 서울 소재 5 개 실내 스포츠 클라이밍 센터에서 이루어졌다. 특정 지역에 편중되 지 않는 자료 수집을 위하여 서대문구, 은평구, 강서 구, 강남구, 송파구에 위치한 실내 스포츠 클라이밍 센터에서 2016년 1월 18일부터 2월 2일까지 설문조 사를 실시하였다. 조사대상자는 스포츠 클라이밍 운 동을 주기적으로 하는 남성 82명과 여성 70 명이었다. 응답자의 평균 연령은 남성이 31.8세 $(\mathrm{SD}=8.22)$, 여성 이 28.2세 $(\mathrm{SD}=5.34)$ 이었다(Table 1). 남성 응답자들의 연령은 주로 25 29세(31.7\%)와 30 34세(22.0\%)가 많 았고, 40 세 이상도 $14.6 \%$ 포함되었다. 반면 여성들은 25 29세(41.4\%)가 가장 많았으며 20 24세는 $18.6 \%$, $30 ~ 34$ 세는 $21.4 \%$ 이었고, 40 대 이상 $(2.9 \%)$ 은 매우 드

<Table 1> Demographic characteristics of subjects

\begin{tabular}{|c|c|c|c|}
\hline \multirow{2}{*}{\multicolumn{2}{|c|}{ Variable }} & \multicolumn{2}{|c|}{ Frequency $(\%)$} \\
\hline & & \multirow{2}{*}{$\begin{array}{c}\begin{array}{c}\text { Male } \\
(n=82)\end{array} \\
5(6.1)\end{array}$} & \multirow{2}{*}{$\begin{array}{c}\begin{array}{c}\text { Female } \\
(n=70)\end{array} \\
3(4.3)\end{array}$} \\
\hline \multirow{6}{*}{$\begin{array}{l}\text { Age } \\
\text { (year) }\end{array}$} & Less than 20 & & \\
\hline & $20 \sim 24$ & $7(8.5)$ & $13(18.6)$ \\
\hline & $25 \sim 29$ & $26(31.7)$ & $29(41.4)$ \\
\hline & $30 \sim 34$ & $18(22.0)$ & $15(21.4)$ \\
\hline & $35 \sim 39$ & $14(17.1)$ & $8(11.4)$ \\
\hline & Over 40 & $12(14.6)$ & $2(2.9)$ \\
\hline \multirow{3}{*}{$\begin{array}{c}\text { Participation/ } \\
\text { week }\end{array}$} & Less than once & $2(2.4)$ & $2(5.7)$ \\
\hline & $1 \sim 3$ times & $28(34.1)$ & $34(48.6)$ \\
\hline & Over 3 times & $52(63.4)$ & $32(45.7)$ \\
\hline \multirow{5}{*}{$\begin{array}{l}\text { Experience } \\
\text { period }\end{array}$} & Less than 3 months & $29(35.4)$ & $24(34.3)$ \\
\hline & $3 \sim 6$ months & $17(20.7)$ & $20(28.6)$ \\
\hline & 6 months $\sim 1$ year & $12(14.6)$ & $11(15.7)$ \\
\hline & $1 \sim 3$ years & $13(15.9)$ & $14(20.0)$ \\
\hline & Over 3 years & $11(13.4)$ & $1(1.4)$ \\
\hline
\end{tabular}

물었다. 조사 대상자의 연령 집단은 등산복 착용실태 조사연구(Lee, 2010)와 패션 아웃도어웨어 시장 분석 연구(Kim, 2013)를 참고하여 분류하였다. 응답자들이 스포츠 클라이밍 활동에 참여하는 빈도는 남녀 모두 매우 높았다. 주 3회 이상 스포츠 클라이밍 활동을 수 행한다고 응답한 사람은 남성이 $63.4 \%$ 이었고, 여성이 $45.7 \%$ 이었다. 응답자들의 스포츠 클라이밍 운동 경 력 기간은 3 개월 미만부터 3 년 이상까지 다양하였다.

\section{2) Questionnaire}

선행연구(Jung \& Chun, 2013; Lee, 2010; Lee \& Eum, 2012; Lee, Jeong, \& Kim, 2009; Seo \& Chun, 2014)를 참조하여 스포츠 클라이밍 시 착용하는 팬츠의 종류와 기능적 디자인에 대한 수요 조사 항목을 다음 과 같이 설정하였다. 스포츠 클라이밍 시 착용하는 팬 츠의 종류는 '클라이밍 전용 팬츠(climbing expert style pants)', '아웃도어 등산용 팬츠(outdoor mountaineering style pants)', '레깅스 스타일 스포츠 팬츠(leggings style sport pants)', '컴프레션 스타일 팬츠(compression style pants)', '일반 운동복 팬츠(training pants)'의 5 가지 유형으로 구분하여 조사하였다. 본 연구에서는 클라 이밍 전용 팬츠를 실내 또는 실외 암벽등반 전용으로 제작한 팬츠로 정의하였고, 아웃도어 등산용 팬츠는 일반적인 등산용 팬츠로 정의하였다. 레깅스 스타일 스포츠 팬츠는 신축성이 우수한 소재를 사용하여 피 부에 밀착시켜 착용하도록 제작한 스포츠웨어 팬츠 로 정의하였고, 컴프레션 스타일 팬츠는 근육 부위에 따라 부분적으로 차등 압박을 주기 위하여 피부에 밀 착되도록 제작한 팬츠로 정의하였다. 일반 운동복 팬 츠는 일상 생활에서 범용적으로 착용되는 운동복 바 지로 정의하였다. 스포츠 클라이밍용 팬츠의 핏은 의복 의 여유분을 나타내는 실루엣(silhouette)과 압박(pressure) 정도의 2 가지 요소로 나누어 조사하였다. 실루엣은 신체의 실루엣이 전혀 드러나지 않는 '루즈핏(loose fit)'과 신체의 실루엣이 약간 드러나는 정도의 여유분 을 갖는 '세미 타이트 핏(semi tight fit)', 신체 실루엣 이 두드러지게 드러날 정도의 '타이트 핏(tight fit)'으 로 분류하였다. 압박 정도는 '압박감 없음(no pressure)', ‘약간의 압박감 있음(low pressure)', ‘하반신을 고르 게 조이는 압박감 있음(evenly tighten pressure)', ‘부 분적으로 강한 압박감 있음(partially strong pressure)' 
으로 분류하여 조사하였다. 스포츠 클라이밍시 응답자 들이 착용하는 팬츠의 유형과 선호하는 팬츠의 실루 엣 및 압박 정도는 다중 선택 방식으로 측정하였다.

스포츠 클라이밍용 팬츠를 구매할 때 중요하게 고 려하는 기능적 디자인 수요는 동작적응성(motion adaptability), 쾌적성(comfort), 미적(aesthetic) 요소로 분류하여 조사하였다(Table 2). 동작적응성은 다시 스 포츠 클라이밍 동작 수행을 방해하지 않는 '기동성 (mobility)'과 스포츠 클라이밍 동작 수행중 팬츠가 흘러내리거나 밀리지 않도록 하는 '위치 안정성(stability)'으로 나누어 조사하였다. 기동성은 앞허리, 둔 부, 샅부위, 넙다리, 무릎부위의 원활한 동작수행에 대하여 조사하였고, 위치 안정성은 동작 시 뒤허리선 과 바지 밑단선이 내려가거나 올라가지 않는지 등에 대하여 조사하였다. 쾌적성은 봉제선이 피부에 쓸리 는 불쾌감(uncomfortable seam lines)과 적절한 정도 의 압박감이 있는지(suitable pressure)에 대하여 조사 하였다. 미적 요소는 적절한 피트성(appropriate fit)과 몸매를 돋보이게 해주는 기능(body shaping)으로 나 누어 조사하였다.

\section{3) Data analysis}

클라이밍 팬츠의 착의 현황과 선호하는 디자인적 요소에 대한 수요조사 자료는 성별 및 클라이밍 경력 에 따라 분석하였다. 디자인적 요소에 대한 수요조사

$<$ Table 2> Functional demands for sports climbing pants

\begin{tabular}{|c|c|c|}
\hline \multirow{8}{*}{$\begin{array}{c}\text { Motion } \\
\text { adaptability }\end{array}$} & \multirow{5}{*}{ Mobility } & Front waist area \\
\hline & & Buttocks area \\
\hline & & Crotch part \\
\hline & & Thigh area \\
\hline & & Knee area \\
\hline & \multirow{3}{*}{ Stability } & Back waist line \\
\hline & & Hemline \\
\hline & & Whole area of pants \\
\hline \multirow{2}{*}{ Comfort } & \multicolumn{2}{|c|}{ Uncomfortable seam lines } \\
\hline & \multicolumn{2}{|c|}{ Suitable pressure } \\
\hline \multirow{2}{*}{ Aesthetic } & \multicolumn{2}{|c|}{ Appropriate fit } \\
\hline & \multicolumn{2}{|c|}{ Body shaping } \\
\hline
\end{tabular}

중 스포츠 클라이밍 활동 시 착용하는 팬츠의 종류와 선호하는 핏의 실루엣 및 압박 정도는 다중 선택 방 식으로 조사하였다. 동작적응성, 위치안정성, 쾌적성, 미적 요소에 대한 응답은 5점 척도로 측정하였다. 통 계 분석 프로그램은 SPSS Statistics 23을 사용하였다.

\section{Market research}

\section{1) Data collection}

국내에서 판매 중인 클라이밍 팬츠의 디자인 특성 을 파악하기 위하여 2016 2017 Fall/Winter 시즌에 판매되었던 9 개 브랜드의 클라이밍용 팬츠 디자인을 분석하였다. 조사 대상 브랜드는 '클라이밍 전용 스 포츠웨어를 주로 판매하는 브랜드(CSB)', '클라이밍 용 스포츠웨어 라인을 운영하는 아웃도어 스포츠웨 어 브랜드(OWC)', '클라이밍 라인을 보유하지 않은 일반 아웃도어 스포츠웨어 브랜드 $(\mathrm{GO})^{\prime}$ '의 3 가지 유 형으로 분류하였다(Table 3). 분석 대상 자료는 각 스 포츠웨어 브랜드의 공식 웹사이트에서 수집하였으며,

$<$ Table 3> Research pants and brands distribution

\begin{tabular}{|c|c|c|c|}
\hline \multirow[b]{2}{*}{ Brand types } & \multirow[b]{2}{*}{ Brands } & \multicolumn{2}{|c|}{ Number of pants } \\
\hline & & $\begin{array}{l}\text { Men's } \\
(n=33)\end{array}$ & $\begin{array}{c}\text { Women's } \\
(n=34)\end{array}$ \\
\hline \multirow{4}{*}{$\begin{array}{c}\text { Climbing } \\
\text { sportswear brands } \\
(\mathrm{CSB})\end{array}$} & A & 15 & 10 \\
\hline & B & 2 & 5 \\
\hline & $\mathrm{C}$ & 2 & 5 \\
\hline & Total & 19 & 20 \\
\hline \multirow{4}{*}{$\begin{array}{l}\text { Outdoor sportswear } \\
\text { brands with } \\
\text { climbing line } \\
\text { (OWC) }\end{array}$} & $\mathrm{D}$ & 2 & 3 \\
\hline & $\mathrm{E}$ & 4 & 3 \\
\hline & $\mathrm{F}$ & 4 & 3 \\
\hline & Total & 10 & 9 \\
\hline \multirow{4}{*}{$\begin{array}{c}\text { General outdoor } \\
\text { sportswear brands } \\
(\mathrm{GO})\end{array}$} & $\mathrm{G}$ & 2 & 3 \\
\hline & $\mathrm{H}$ & 1 & 1 \\
\hline & I & 1 & 1 \\
\hline & Total & 4 & 5 \\
\hline
\end{tabular}

Brands : Black diamond, EiDER, E9, KOLON SPORT, LA SPORTIVA, MOON CLIMBING, patagonia, THE NORTH FACE, VERVE CLIMBING 
남성용 팬츠 디자인 33 개와 여성용 팬츠 디자인 34개 를 분석하였다. 분석 대상은 GSB 브랜드 유형이 가 장 많았고, $\mathrm{GO}$ 브랜드 유형이 가장 적었다.

\section{2) Data analysis}

클라이밍용 팬츠의 기능적인 디자인 특성은 여유 분의 정도(fit), 허리밴드 형태, 샅부위 형태, 무릎 형 태, 밑단 형태를 중심으로 분석하였다(Fig. 2). 클라이 밍 팬츠의 여유분 정도(fit)는 하반신 실루엣이 전혀 드러나지 않을 정도로 여유있는 '루즈핏(loose fit)', 약간의 여유가 있는 ‘슬림핏(slim fit)', 신체에 밀착되 어 여유분이 없는 '타이트핏(tight fit)'의 세 가지로 구 분하여 조사하였다. 허리밴드 형태는 '조임 스트링 없 이 신축성 밴드만을 사용한 형태(elastic band)'와 신 축성 밴드에 허리 조임 스트링을 부착한 '스트링 부착 신축성 밴드 형태(elastic band with string)', 조임 스 트링이나 신축성 밴드를 사용하지 않는 '기본형 허리 밴드(basic)'로 분류하였다. 샅부위 형태는 다이아몬 드형 '무(gusset)를 샅부위에 부착한 형태'와 일반적 인 ‘기본형(basic)'으로 구분하였다. 무릎부위 형태는 입체적인 제작 방법을 사용하여 옷걸이에 걸린 상태 에서도 무릎이 약간 굴곡된 실루엣을 유지하는 ‘입체 형(articulated knee)'과 일반적인 '기본형(basic)'으로 구분하였다. 밑단의 형태는 착용자가 ‘스트링으로 밑 단 폭을 조절하여 착용할 수 있게 설계한 형태(string hem)'와 '신축성 밴드를 사용한 형태(elastic band hem)', 특별한 설계를 하지 않은 일반적인 '기본형(basic)'으 로 구분하였다.

\section{Result and Discussion}

\section{Type of sports pants}

스포츠 클라이머들이 클라이밍 운동 시 착용하는 팬츠의 종류는 성별에 따라 뚜렷한 차이를 나타냈다 (Table 4). 남성이 여성보다 더 높은 착용률을 나타낸 팬츠는 클라이밍 전용 팬츠 $(p<.05)$ 와 아웃도어용으로 판매되는 등산용 팬츠 $(p<.01)$ 이었고, 여성이 남성보다 더 높은 착용률을 나타낸 팬츠는 레깅스 스타일 스포 츠 팬츠였다 $(p<.001)$. 일반 운동복 팬츠는 남녀 모두 착용 빈도가 높았고, 컴프레션 스타일 팬츠는 남녀 모 두 착용 빈도가 낮았다. 따라서 스포츠 클라이머들이

(a) Fit

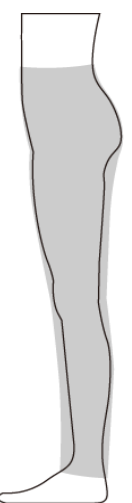

Slim fit

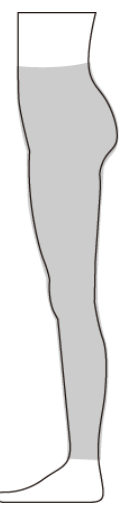

Tight fit

(b) Waist band

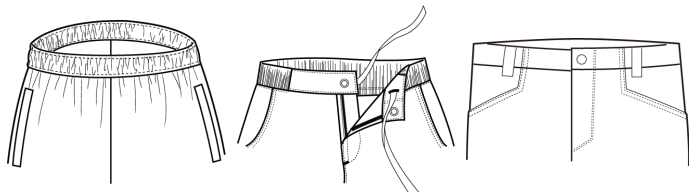

Elastic band with string

(c) Crotch

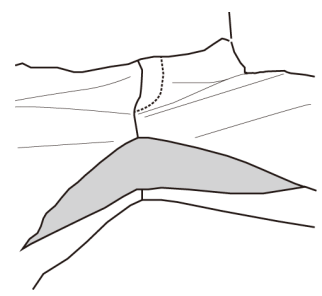

Gusset insert

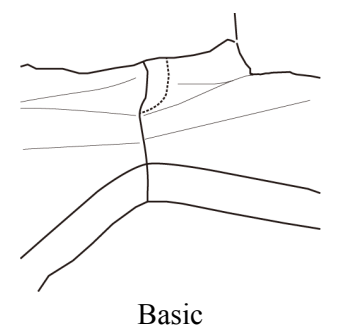

(d) Knee

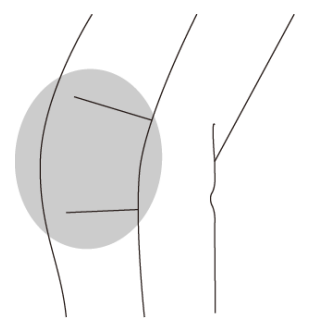

Articulated knee

(e) Hem

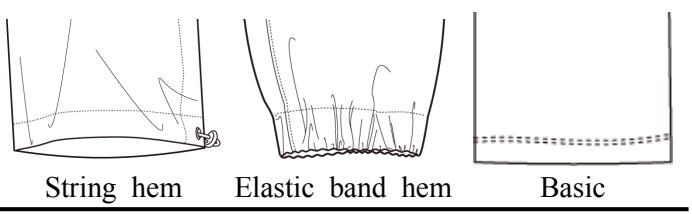

<Fig. 2> Design elements of the climbing pants 
$<$ Table $4>$ Selections of the pants types by gender

$($ Male $=82$, Female $=70)$

\begin{tabular}{|c|c|c|c|c|c|}
\hline Pants types & Gender & $\begin{array}{l}\text { Frequency of } \\
\text { selection }(\%)\end{array}$ & $\chi^{2}$ & $d f$ & $p$-value \\
\hline \multirow{2}{*}{ Climbing expert style pants } & Male & $23(28.0)$ & \multirow{2}{*}{6.425} & \multirow{2}{*}{1} & \multirow{2}{*}{.011} \\
\hline & Female & $8(11.4)$ & & & \\
\hline \multirow{2}{*}{ Outdoor mountaineering style pants } & Male & $36(43.9)$ & \multirow{2}{*}{8.555} & \multirow{2}{*}{1} & \multirow{2}{*}{.003} \\
\hline & Female & $15(21.4)$ & & & \\
\hline \multirow{2}{*}{ Leggings style sport pants } & Male & $14(17.1)$ & \multirow{2}{*}{52.682} & \multirow{2}{*}{1} & \multirow{2}{*}{.000} \\
\hline & Female & $52(75.7)$ & & & \\
\hline \multirow{2}{*}{ Compression style pants } & Male & $3(4.7)$ & \multirow{2}{*}{0.039} & \multirow{2}{*}{1} & \multirow{2}{*}{.843} \\
\hline & Female & $3(4.3)$ & & & \\
\hline \multirow{2}{*}{ Training pants } & Male & $67(81.7)$ & \multirow{2}{*}{2.864} & \multirow{2}{*}{1} & \multirow{2}{*}{.091} \\
\hline & Female & $49(70.0)$ & & & \\
\hline
\end{tabular}

거의 착용하지 않는 컴프레션 스타일 팬츠를 제외하 고, 클라이밍 전용 팬츠, 아웃도어 등산용 팬츠, 레깅 스 스타일 스포츠 팬츠, 일반 운동복 팬츠를 중심으 로 스포츠 클라이밍 참여 기간에 따른 착용 특성을 분석하였다.

스포츠 클라이밍에 참여한 기간에 따른 팬츠 스타 일의 착용률을 분석한 결과, 남성과 여성의 차이가 뚜렷하였다(Table 5). 남성들의 경우, 6개월 이상 경 력자부터 클라이밍 전용 팬츠를 착용하는 경향을 나 타냈으며, 참여기간이 1년 이상이 된 이후에는 클라 이밍 전용 팬츠의 착용률이 급격히 상승하였고 $(p<$ $0.001)$, 아웃도어 등산용 팬츠는 6 개월 이상 참여자부 터 착용률이 크게 증가하였다 $(p<0.01)$. 일반 운동복 팬츠 착용 경향은 남성의 경우, 스포츠 클라이밍 경 력이 6개월 이상 1년 미만인 집단만을 제외하고 모든 경력기간 집단에서 $80 \%$ 이상의 착용률을 나타냈다 $(p<0.001)$, 반면 여성들은 스포츠 클라이밍을 시작하는 초기부터 레깅스 스타일 스포츠 팬츠를 착용하는 비 율이 높았다. 3 개월 이상 클라이밍에 참여한 여성들 은 $85 \%$ 이상이 레깅스 스타일 스포츠 팬츠를 착용하 였다 $(p<.05)$. 아웃도어 등산용 팬츠는 여성의 경우, 6 개월 이상 참여자부터 $40 \%$ 내외의 착용률을 보였다 $(p<.05)$. 일반 트레이닝복 팬츠는 스포츠 클라이밍 경 력기간이 3 개월 이하인 초기 단계에서는 남성보다 약
간 높은 착용률(87.5\%)을 나타냈으나, 스포츠 클라이 밍 경력이 증가할수록 착용률이 점차 감소하였다.

\section{Fit preferences}

스포츠 클라이밍용 팬츠 스타일의 피트성 요소에 대한 선호도를 실루엣(silhouette)과 압박(pressure)정 도로 조사한 결과, 성별에 따라 약간 다르게 나타났 다(Table 6). 남녀 모두 보편적으로 선호하는 실루엣 은 지나치게 헐렁하거나 타이트하지 않고, 하체 실루 엣이 거의 드러나지 않는 핏(semi tight fit)이었으나 (남성 $72.0 \%$, 여성 $65.7 \%$ ), 그 다음으로 선호한 스타 일은 남성의 경우 여유분이 많은 핏(loose fit)이었고 (37.8\%), 여성의 경우 신체 실루엣이 드러날 정도의 타이트한 핏(tight fit)이었다(54.3\%).

압박 정도는 남녀 모두 약간의 압박감이 있는 스타 일(low pressure)에 대한 선호도가 높았다(남성 52.4\%, 여성 $57.1 \%$ ). 그 다음으로 선호한 압박 정도는 남성 의 경우 착용 시 압박감이 전혀 없는 스타일(no pressure)이었고(40.2\%), 여성의 경우 전체적으로 고르게 조이는 압박감이 있는 스타일(evenly tighten pressure) 이었다(40.0\%). 부분적으로 강한 압박감을 주는 스타 일(partially strong pressure)에 대하여 남성들은 매우 낮은 선호도 $(8.5 \%)$ 를 나타냈으나 여성들은 남성들보 다 더 높은 선호를 나타냈다(20.0\%). 
$<$ Table $5>$ Selections of the pants types by experience period

\begin{tabular}{|c|c|c|c|c|c|c|c|c|c|}
\hline \multirow{2}{*}{ Pants types } & \multirow{2}{*}{ Experience period } & \multicolumn{4}{|c|}{ Male } & \multicolumn{4}{|c|}{ Female } \\
\hline & & Frequency $(\%)$ & $\chi^{2}$ & $d f$ & $p$-value & Frequency $(\%)$ & $\chi^{2}$ & $d f$ & $p$-value \\
\hline \multirow{5}{*}{$\begin{array}{c}\text { Climbing } \\
\text { experts' pants } \\
(\text { Male }=23, \\
\text { Female }=8)\end{array}$} & Less than 3 months & $0(0.0)$ & \multirow{5}{*}{30.487} & \multirow{5}{*}{4} & \multirow{5}{*}{.000} & $1(4.2)$ & \multirow{5}{*}{4.072} & \multirow{5}{*}{3} & \multirow{5}{*}{.254} \\
\hline & $3 \sim 6$ months & $3(17.6)$ & & & & $2(10.0)$ & & & \\
\hline & 6 months $\sim 1$ year & $4(33.3)$ & & & & $3(27.3)$ & & & \\
\hline & $1 \sim 3$ years & $8(61.5)$ & & & & $2(13.3)$ & & & \\
\hline & Over 3 years & $8(72.7)$ & & & & - & & & \\
\hline \multirow{5}{*}{$\begin{array}{c}\text { Outdoor } \\
\text { mountaineering } \\
\text { pants } \\
(\text { Male }=36, \\
\text { Female }=15)\end{array}$} & Less than 3 months & $8(27.6)$ & \multirow{5}{*}{13.878} & \multirow{5}{*}{4} & \multirow{5}{*}{.008} & $1(4.2)$ & \multirow{5}{*}{8.802} & \multirow{5}{*}{3} & \multirow{5}{*}{.032} \\
\hline & $3 \sim 6$ months & $4(23.5)$ & & & & $4(20.0)$ & & & \\
\hline & 6 months $\sim 1$ year & $8(66.7)$ & & & & $4(36.4)$ & & & \\
\hline & $1 \sim 3$ years & $8(61.5)$ & & & & $6(40.0)$ & & & \\
\hline & Over 3 years & $8(72.7)$ & & & & - & & & \\
\hline \multirow{5}{*}{$\begin{array}{c}\text { Leggings style } \\
\text { sport pants } \\
(\text { Male }=14, \\
\text { Female }=53)\end{array}$} & Less than 3 months & $4(13.8)$ & \multirow{5}{*}{1.548} & \multirow{5}{*}{4} & \multirow{5}{*}{.818} & $13(54.2)$ & \multirow{5}{*}{9.358} & \multirow{5}{*}{3} & \multirow{5}{*}{.025} \\
\hline & $3 \sim 6$ months & $4(23.5)$ & & & & $17(85.0)$ & & & \\
\hline & 6 months $\sim 1$ year & $2(16.7)$ & & & & $10(90.9)$ & & & \\
\hline & $1 \sim 3$ years & $3(23.1)$ & & & & $13(85.7)$ & & & \\
\hline & Over 3 years & $1(9.1)$ & & & & - & & & \\
\hline \multirow{5}{*}{$\begin{array}{l}\text { Training type } \\
(\text { Male }=67, \\
\text { Female }=49)\end{array}$} & Less than 3 months & $25(86.2)$ & \multirow{5}{*}{23.683} & \multirow{5}{*}{4} & \multirow{5}{*}{.000} & $21(87.5)$ & \multirow{5}{*}{5.934} & \multirow{5}{*}{3} & \multirow{5}{*}{.115} \\
\hline & $3 \sim 6$ months & $17(100.0)$ & & & & $13(65.0)$ & & & \\
\hline & 6 months $\sim 1$ year & $4(33.3)$ & & & & $7(63.6)$ & & & \\
\hline & $1 \sim 3$ years & $11(84.6)$ & & & & $8(53.3)$ & & & \\
\hline & Over 3 years & $10(90.9)$ & & & & - & & & \\
\hline
\end{tabular}

$<$ Table 6> Preference of silhouette and pressure by gender

$($ Male $=82$, Female $=70)$

\begin{tabular}{|c|c|c|c|c|c|c|}
\hline & Classification & Gender & $\begin{array}{c}\text { Frequency of } \\
\text { preferences }(\%)\end{array}$ & $\chi^{2}$ & $d f$ & $p$-value \\
\hline \multirow{6}{*}{ Silhouette } & \multirow{2}{*}{ Loose fit } & Male & $31(37.8)$ & \multirow{2}{*}{6.792} & \multirow{2}{*}{1} & \multirow{2}{*}{.009} \\
\hline & & Female & $13(18.6)$ & & & \\
\hline & \multirow{2}{*}{ Semi tight fit } & Male & $59(72.0)$ & \multirow{2}{*}{0.688} & \multirow{2}{*}{1} & \multirow{2}{*}{.407} \\
\hline & & Female & $46(65.7)$ & & & \\
\hline & \multirow{2}{*}{ Tight fit } & Male & $10(12.2)$ & \multirow{2}{*}{30.964} & \multirow{2}{*}{1} & \multirow{2}{*}{.000} \\
\hline & & Female & $38(54.3)$ & & & \\
\hline \multirow{8}{*}{ Pressure } & \multirow{2}{*}{ No pressure } & Male & $33(40.2)$ & \multirow{2}{*}{8.404} & \multirow{2}{*}{1} & \multirow{2}{*}{.004} \\
\hline & & Female & $13(18.6)$ & & & \\
\hline & \multirow{2}{*}{ Low pressure } & Male & $43(52.4)$ & \multirow{2}{*}{0.337} & \multirow{2}{*}{1} & \multirow{2}{*}{.562} \\
\hline & & Female & $40(57.1)$ & & & \\
\hline & \multirow{2}{*}{ Evenly tighten pressure } & Male & $11(13.4)$ & \multirow{2}{*}{13.992} & \multirow{2}{*}{1} & \multirow{2}{*}{.000} \\
\hline & & Female & $28(40.0)$ & & & \\
\hline & \multirow{2}{*}{ Partially strong pressures } & Male & $7(8.5)$ & \multirow{2}{*}{4.168} & \multirow{2}{*}{1} & \multirow{2}{*}{.041} \\
\hline & & Female & $14(20.0)$ & & & \\
\hline
\end{tabular}




\section{Needs for functional design elements}

스포츠 클라이밍용 팬츠의 기능적 요소에 대한 수 요를 동작적응성(motion adaptability), 쾌적성(comfort), 미적(aesthetic) 요소로 나누어 조사한 결과, 일반적으 로 남녀 모두 높은 관심을 가지고 있었다(Table 7, Over 3.0 consideration), 특히 여성들이 남성들보다 거
의 모든 기능적 요소에 대하여 더 높은 관심을 나타 냈다.

동작적응성을 기동성(mobility)과 위치 안정성(stability)으로 분류하여 조사한 결과, 기동성에 대해서는 여성들이 남성들보다 앞허리부위 $(p<.001)$, 엉덩이부 위 $(p<.01)$, 샅부위 $(p<.01)$ 에서 높은 수요를 나타냈다.

$<$ Table 7> Demand of functionality for sports climbing pants

$($ Male $=82$, Female $=70)$

\begin{tabular}{|c|c|c|c|c|c|c|c|c|}
\hline \multirow{2}{*}{\multicolumn{3}{|c|}{ Functional design demands }} & \multirow{3}{*}{$\begin{array}{c}\text { Gender } \\
\text { Male }\end{array}$} & \multicolumn{2}{|c|}{ Consideration } & \multirow{3}{*}{$\begin{array}{l}t \text {-value } \\
-4.176\end{array}$} & \multirow{3}{*}{$\begin{array}{c}d f \\
150\end{array}$} & \multirow{3}{*}{$\begin{array}{r}p \text {-value } \\
.000\end{array}$} \\
\hline & & & & & & & & \\
\hline \multirow{16}{*}{$\begin{array}{l}\text { Motion } \\
\text { adapt- } \\
\text { ability }\end{array}$} & \multirow{10}{*}{ Mobility } & \multirow{2}{*}{ Front waist area } & & $\begin{array}{c}\text { Mean } \\
2.8\end{array}$ & $\begin{array}{l}\text { s.d. } \\
1.06\end{array}$ & & & \\
\hline & & & Female & 3.5 & 0.88 & & & \\
\hline & & \multirow{2}{*}{ Buttocks area } & Male & 3.8 & 0.97 & \multirow{2}{*}{-3.510} & \multirow{2}{*}{150} & \multirow{2}{*}{.001} \\
\hline & & & Female & 4.3 & 0.73 & & & \\
\hline & & \multirow{2}{*}{ Crotch part } & Male & 3.8 & 0.94 & \multirow{2}{*}{-3.225} & \multirow{2}{*}{150} & \multirow{2}{*}{.002} \\
\hline & & & Female & 4.2 & 0.75 & & & \\
\hline & & \multirow{2}{*}{ Thigh area } & Male & 3.8 & 0.96 & \multirow{2}{*}{-1.575} & \multirow{2}{*}{150} & \multirow{2}{*}{.117} \\
\hline & & & Female & 4.0 & 0.83 & & & \\
\hline & & \multirow{2}{*}{ Knee area } & Male & 3.8 & 1.06 & \multirow{2}{*}{-1.903} & \multirow{2}{*}{147.763} & \multirow{2}{*}{.059} \\
\hline & & & Female & 4.1 & 0.80 & & & \\
\hline & \multirow{6}{*}{ Stability } & \multirow{2}{*}{ Back waist line } & Male & 3.1 & 1.11 & \multirow{2}{*}{-9.438} & \multirow{2}{*}{140.050} & \multirow{2}{*}{.000} \\
\hline & & & Female & 4.5 & 0.72 & & & \\
\hline & & & Male & 2.7 & 1.03 & & & \\
\hline & & & Female & 3.3 & 1.10 & & & \\
\hline & & & Male & 3.7 & 1.15 & & & \\
\hline & & vinute area or pants & Female & 4.1 & 0.81 & 2.114 & 140.401 & .030 \\
\hline & & Uncomfortable seam & Male & 3.2 & 1.22 & & & \\
\hline & fort & lines & Female & 3.6 & 1.12 & $2.1 / \mathrm{J}$ & & .001 \\
\hline & & & Male & 2.9 & 1.15 & & & \\
\hline & & Surtaumity piessure & Female & 3.4 & 0.92 & 2.700 & 100 & .004 \\
\hline & & & Male & 3.1 & 1.13 & & & \\
\hline & & & Female & 3.6 & 0.87 & & 140.507 & .001 \\
\hline & & & Male & 2.7 & 1.16 & & & \\
\hline & & 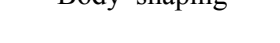 & Female & 3.6 & 1.08 & & & \\
\hline
\end{tabular}

$1=$ Not considered at all, 2=Not considered, 3=Moderate, $4=$ Considered, $5=$ Highly considered Over 3.0 consideration 
또한 여성들은 고관절의 외전과 굴곡이 크게 나타나 는 후킹 자세(Fig. 1(a))와 고관절 및 무릎관절을 크게 굴곡시키는 몽키 행 자세(Fig. 1(d)) 등을 취할 때 허 리 밴드가 아래로 당겨져서 뒤허리가 노출되는 것 $(p<$ $.001)$ 과 바지 밑단이 딸려 올라가는 것 $(p<.001)$ 을 방 지하는 기능에 대한 수요가 높게 나타났다. 쾌적감에 대한 수요도 여성이 남성보다 높았다. 여성들은 봉제 선의 쓸림을 방지하는 기능 $(p<.05)$ 과 적절한 정도의 압박이 있는 기능 $(p<.01)$ 에 대한 수요가 남성보다 높 았다. 또한 여성들은 적절한 맞음새를 유지하고 $(p<$ $.01)$, 신체 실루엣이 좋게 보이게 하는 기능 $(p<.001)$ 에 대해서도 남성보다 더 높은 수요를 나타냈다.

이러한 분석 결과는 스포츠 클라이밍용 팬츠를 구 매할 때 여성들이 활동 시의 기동성과 안정성에 대해 남성들보다 까다로운 선택 기준을 가지고 있음을 보 여 준다. 이외에도 여성들은 클라이밍 동작을 수행할 때에도 신체가 노출되지 않고, 신체 실루엣이 아름답 게 보이는 것을 기대하므로 여성용 클라이밍 팬츠 설 계시 이러한 여성들의 기능적 디자인에 대한 수요를
반영하여 개발할 필요가 있음을 시사한다.

\section{Market research}

국내에서 판매되고 있는 클라이밍 팬츠의 기능적 디자인 요소들을 분석한 결과는 다음과 같다. 실루엣 (fit)의 경우, 레깅스 스타일과 같은 타이트핏(tight fit) 팬츠는 여성용으로만 판매한다는 공통적인 경향도 있었으나, 브랜드의 유형에 따라 주로 반영하는 요소 에 차이가 있었다(Table 8). 클라이밍용 스포츠웨어를 전문적으로 판매하는 브랜드(CSB)는 주로 루즈핏(loose fit) 스타일 팬츠가 많았고(남성용 $78.9 \%$, 여성용 $45.0 \%$ ), 슬림핏(slim fit)의 팬츠도 상당 비율로 판매하고 있었 다(남성용 $21.1 \%$, 여성용 $40.0 \%$ ). 브랜드 유형별로 비 교하면 클라이밍 라인을 보유한 아웃도어 스포츠웨어 브랜드(OWC)들은 남성용(90.0\%)과 여성용(66.7\%) 모두 루즈핏 제품이 많았으나, 클라이밍 스포츠웨어 라인을 운영하지 않는 일반 아웃도어 스포츠웨어 브 랜드 $(\mathrm{GO})$ 는 대부분 슬림핏의 팬츠가 많았다. 클라이 밍 전용 팬츠의 개발 라인이 없는 일반 아웃도어 브

$<$ Table 8> Fit distribution of the climbing pants by the brand type

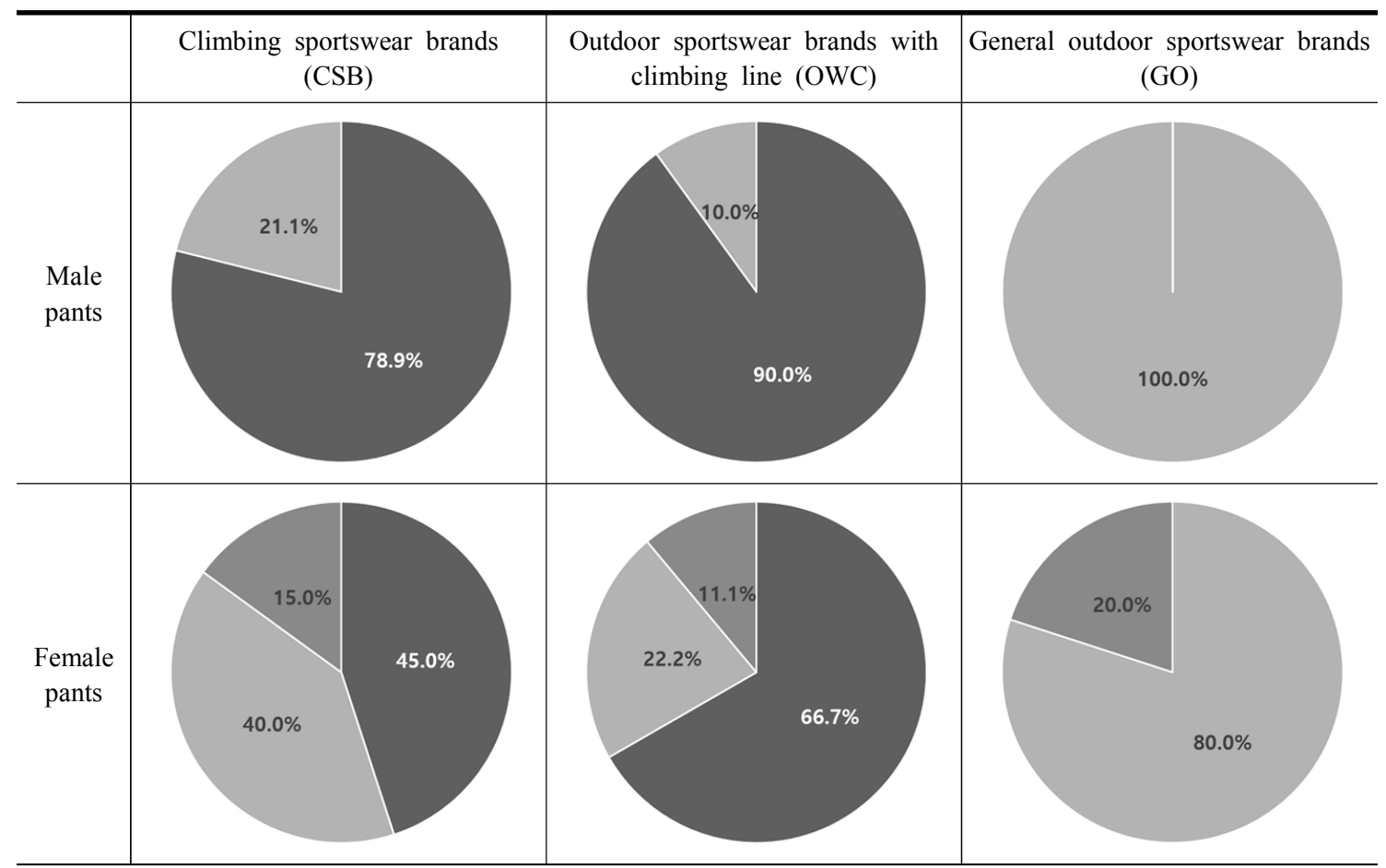

Note: $\quad$ Loose fit $\square$ Slim fit $\square$ Tight fit 
랜드 $(\mathrm{GO})$ 에서는 주로 슬림핏의 팬츠를 판매하는 반 면, 클라이밍 전용 팬츠를 판매하는 클라이밍 전문 브랜드(CSB)와 아웃도어 브랜드(OWC)에서는 여유 분이 많은 루즈핏(loose fit)의 팬츠를 주로 생산한다 는 본 연구의 결과는 클라이밍 동작 수행 시 불편함 이 없도록 하기 위해 슬림핏보다는 루즈핏 팬츠의 비 율을 높인 것이라고 해석할 수 있다.

허리밴드, 샅부위, 무릎부위, 밑단의 형태 특징을 분석한 결과는 다음과 같다(Table 9). 허리밴드 형태 는 남성용 팬츠의 경우, 신축성 밴드에 스트링을 부 착하는 형태를 많이 사용하였다. 이는 클라이밍 동작 수행을 방해하지 않고 착용자가 편안함을 느끼게 하 기 위함으로 해석된다. 브랜드 유형별로는 클라이밍 전문 스포츠웨어 브랜드(CSB)는 신축성 밴드에 허리 조임 스트링을 추가한 방식을 주로 사용하였으나 $(78.9 \%)$, 일반 아웃도어 스포츠웨어 브랜드 $(\mathrm{GO})$ 는 허리조임 스트링이 없는 신축성 밴드를 주로 사용하였다(75.0\%). 클라이밍 아웃도어 스포츠웨어 브랜드(OWC)는 일반 형 허리밴드(basic, $40.0 \%$ )와 신축성 밴드형 허리밴드 (elastic band, $50.0 \%$ )를 고르게 사용하였다. 남성용 팬츠에서 스트링이 있는 신축성 허리밴드의 사용율
이 높았던 것과는 다르게 여성용 팬츠는 클라이밍 전 문 스포츠웨어 브랜드(CSB, $60.0 \%)$ 와 일반 아웃도어 스포츠웨어 브랜드 $(\mathrm{GO}, 80.0 \%)$ 에서 신축성 허리밴드 를 주로 사용하였다. 클라이밍 아웃도어 스포츠웨어 브랜드(OWC)에서는 신축성 밴드에 허리조임 스트링 을 부착한 허리밴드를 주로 사용하였다(44.4\%). 이는 여성복의 경우 신축성 소재로 제작한 레깅스 스타일 스포츠 팬츠의 비율이 높기 때문일 것으로 해석된다.

팬츠 샅부위 설계 형태의 브랜드 유형별 차이는 다 음과 같다. 클라이밍 전문 스포츠웨어 브랜드(CSB) 의 남성용 팬츠에서는 다이아몬드형 무를 샅부위에 부착하는 형태를 일반적으로 사용하였다(84.2\%). 그 러나 클라이밍 라인을 보유한 아웃도어 스포츠웨어 브랜드(OWC)는 남성용 팬츠의 $40.0 \%$ 만 샅부위에 다 이아몬드형 무를 사용하였다. 여성용 팬츠는 샅부위 에 다이아몬드형 무를 사용한 비율이 남성용보다 낮 았다. 클라이밍 라인을 운영하지 않는 일반 아웃도어 스포츠웨어 브랜드 $(\mathrm{GO})$ 들은 남성용 팬츠와 여성용 팬츠의 샅부위에 다이아몬드형 무를 전혀 사용하지 않았다. 이와 같은 샅부위의 형태와 핏의 출현율을 복합적으로 해석하면 루즈핏 스타일을 주로 사용하

$<$ Table 9> Distribution of detail design elements of the climbing pants by the brand type

Unit: \%

\begin{tabular}{|c|c|c|c|c|c|c|c|}
\hline \multirow[b]{2}{*}{ Detail } & \multirow[t]{2}{*}{ Brand type } & \multicolumn{3}{|c|}{ Men's pants } & \multicolumn{3}{|c|}{ Women's pants } \\
\hline & & $\begin{array}{c}\text { Climbing } \\
\text { sportswear } \\
\text { brands } \\
(\mathrm{CSB}, n=19)\end{array}$ & $\begin{array}{c}\text { Outdoor } \\
\text { sportswear } \\
\text { brands with } \\
\text { climbing line } \\
(\text { OWC, } n=10)\end{array}$ & $\begin{array}{c}\text { General } \\
\text { outdoor } \\
\text { sportswear } \\
\text { brands } \\
(\mathrm{GO}, n=4)\end{array}$ & $\begin{array}{c}\text { Climbing } \\
\text { sportswear } \\
\text { brands } \\
(\mathrm{CSB}, n=20)\end{array}$ & $\begin{array}{c}\text { Outdoor } \\
\text { sportswear } \\
\text { brands with } \\
\text { climbing line } \\
(\text { OWC, } n=9)\end{array}$ & $\begin{array}{c}\text { General } \\
\text { outdoor } \\
\text { sportswear } \\
\text { brands } \\
(\mathrm{GO}, n=5)\end{array}$ \\
\hline \multirow{3}{*}{$\begin{array}{l}\text { Waist } \\
\text { band }\end{array}$} & Elastic band & 15.8 & 10.0 & 75.0 & 60.0 & 22.2 & 80.0 \\
\hline & $\begin{array}{c}\text { Elastic band and } \\
\text { string }\end{array}$ & 78.9 & 50.0 & 25.0 & 30.0 & 44.4 & 20.0 \\
\hline & Basic & 5.3 & 40.0 & 0.0 & 10.0 & 33.3 & 0.0 \\
\hline \multirow{2}{*}{ Crotch } & Gusset insert & 84.2 & 40.0 & 0.0 & 25.0 & 33.3 & 0.0 \\
\hline & Basic & 15.8 & 60.0 & 100.0 & 75.0 & 66.7 & 100.0 \\
\hline \multirow{2}{*}{ Knee } & Articulated knee & 94.7 & 80.0 & 50.0 & 55.0 & 77.8 & 40.0 \\
\hline & Basic & 5.3 & 20.0 & 50.0 & 45.0 & 22.2 & 60.0 \\
\hline \multirow{3}{*}{ Hem } & String & 78.9 & 20.0 & 0.0 & 40.0 & 11.1 & 0.0 \\
\hline & Elastic band & 5.3 & 10.0 & 0.0 & 15.0 & 11.1 & 0.0 \\
\hline & Basic & 15.8 & 70.0 & 100.0 & 45.0 & 77.8 & 100.0 \\
\hline
\end{tabular}


는 남성용 팬츠에서 클라이밍 동작의 기동성을 높이 기 위한 방안으로 샅부위에 다이아몬드형 무를 부착 하는 디자인이 보편화되고 있음을 시사한다.

팬츠의 무릎을 약간 구부린 실루엣으로 표현하는 입체 설계방식(articulated knee)은 모든 유형의 브랜 드에서 높은 사용율을 나타냈다. 이는 입체 설계방식 의 무릎 형태가 스포츠웨어 설계시에 일반화된 기술 임을 보여 준다.

팬츠 밑단에 스트링을 부착하여 착용자가 밑단 폭 을 좁게 조여서 착용할 수 있는 형태의 밑단은 클라 이밍 전문 스포츠웨어 브랜드(CSB)에서 주로 사용하 였다. 남성용 팬츠는 대부분의 팬츠를 스트링 조임 밑 단으로 설계하였으며(78.9\%), 여성용 팬츠도 $40.0 \%$ 는 스트링 조임 밑단을 사용하였다.

\section{Conclusion}

본 연구는 스포츠 클라이밍용 팬츠의 기능적 디자 인 요소에 대한 소비자의 수요를 파악하는 것을 목적 으로 하였다. 설문조사는 스포츠 클라이밍 시 착용하 는 팬츠의 종류, 선호하는 맞음새와 컴프레션 정도, 부위별 디자인 요소에 대하여 조사하였다. 자료분석 은 스포츠 클라이머의 운동 경력 기간과 성별에 따라 분석하였다. 또한 2016 2017 F/W 시즌에 국내에서 판매되었던 남성용과 여성용 클라이밍 팬츠의 디자 인 특징을 분석하여 스포츠 클라이밍용 팬츠의 개발 현황도 분석하였다.

본 연구의 결과는 다음과 같다.

첫째, 스포츠 클라이밍 시 주로 착의하는 팬츠의 유형은 스포츠 클라이밍 운동 경력 기간과 관련이 있 었다. 남성의 경우, 스포츠 클라이밍을 시작한 지 6 개 월 이상 되는 시기부터는 아웃도어 등산용 팬츠를 착 용하기 시작하였고, 참여 기간이 1 년 이상 되는 시기 부터 클라이밍 전용 팬츠의 착용률이 증가하였다. 반 면 여성들은 스포츠 클라이밍 입문 초기부터 레깅스 스타일 스포츠 팬츠를 착용하였다.

둘째, 스포츠 클라이밍 시 착의하는 팬츠의 유형은 성별에 따라 뚜렷한 차이를 나타냈다. 남성들은 타이 트하지 않고 압박감이 거의 없는 스타일을 선호한 반 면에 여성들은 균일하고 가벼운 압박이 하반신 전체 에 고르게 미치며 타이트하게 밀착되는 스타일을 선
호하였다.

셋째, 실내 스포츠 클라이밍용 팬츠를 구매할 때 고려하는 기능적인 디자인 요소에 대한 수요는 여성 이 남성보다 더 구체적이고 다양하였다. 남성들은 둔 부와 샅부위, 넙다리부위, 무릎부위에서 스포츠 클라 이밍 동작 수행에 방해가 되지 않는 기능을 중요하게 고려하였다. 여성들은 스포츠 클라이밍 활동 시 팬츠 가 동작을 방해하지 않는 요소 외에도 운동 중 뒤허 리밴드가 아래로 끌려내려가 신체의 뒤허리가 노출 되는 것에 대하여 민감하였고, 또한 자신의 신체 실 루엣이 매력적으로 보이도록 하는 기능에 대한 기대 도 높았다. 이러한 연구결과는 여성용 스포츠 클라이 밍 팬츠 디자인을 기획할 때 운동 중 신체가 노출되 어 수치심이 느껴지지 않게 함과 동시에 착용후 신체 실루엣이 매력적으로 보이게 해주는 요소도 반영하 여야 함을 시사한다.

넷째, 국내 시중의 스포츠 클라이밍 팬츠 개발 현 황을 분석한 결과, 브랜드의 유형에 따라 주로 반영 하는 기능적 디자인 요소가 다르게 나타났다. 클라이 밍 전문 스포츠웨어 브랜드나 클라이밍 라인을 보유 한 아웃도어 스포츠웨어 브랜드에서는 스포츠 클라 이밍 활동에 특화된 스포츠웨어를 개발하고 있었다. 이들은 팬츠의 허리밴드와 밑단에 신축성 밴드와 사 이즈 조절용 스트링을 부착하여 클라이밍 활동 시 편 안함과 안정감을 추구하였으며, 팬츠의 샅부위에 무 를 부착하거나, 무릎부위를 입체로 제작하여 하지관 절의 동작범위를 높이는 방식을 사용하였다. 이러한 운동기능성 향상 요소들은 여성용보다 남성용 클라 이밍 팬츠의 디자인에 더 집중적으로 반영되는 경향 이 있었다. 여성용 팬츠는 주로 신축성 밴드로 허리 밴드를 제작하는 방식과 무릎 형태를 입체적으로 재 단하는 방식을 사용하였다. 모든 브랜드에서 공통적 으로 사용되고 있는 기능적 디자인 요소는 무릎을 약 간 굽힌 신체 형태를 입체적으로 표현하는 패턴 설계 기술이었다. 이는 무릎부위의 입체적인 패턴 설계 방 식이 바지의 무릎부위 착용감을 크게 개선하면서도 소비자들의 관심을 시각적으로 이끄는 효율적인 디 자인 요소이기 때문일 것으로 사료된다.

본 연구의 결과는 여성 소비자들이 스포츠 클라이 밍 팬츠의 기능적 디자인에 대한 수요가 높은 집단임 을 보여준다. 즉, 여성들은 남성보다 스포츠 클라이밍 
용 팬츠 구매시 운동 동작을 용이하게 하는 기동성과 안정성 외에 적절한 맞음새를 유지하고, 신체 실루엣 이 아름답게 보이도록 하는 미적 기능성을 중요하게 고려하므로 스포츠 클라이밍용 팬츠의 디자인 시에 성별 수요 차이를 반영하는 상품 개발이 필요함을 시 사한다. 따라서 후속 연구에서는 여성 스포츠 클라이 머들의 수요 특성을 반영하여 이들이 주로 착용하는 여성용 스포츠 클라이밍 레깅스의 동작기능성과 쾌 적성, 미적 기능성을 향상시킬 수 있는 기술요소에 대한 구체적인 개발연구가 필요하다.

\section{References}

International Federation of Sport Climbing. (2017). A large and fast-growing worldwide climbing community. iFSC, Retrieved January 30, 2017, from https:/www.ifsc-climbing.org/index.php/media-ce ntre/key-figures-2

Jeong, Y.-J., \& Kim, H.-H. (2014). The relationship between leisure constraints negotiation and recreation specialization of climbing participants. The Korean Journal of Physical Education, 53(3), 581-591.

Johnston, M., \& Koo, H. (2016). Apparel design for female rock climbers: Satisfactions and preferences. International Journal of Fashion Design, Technology and Education. Advance online publication. doi:10.1080/17543266.2016.1223755

Jung, S. M. (2013). Movement functionality in climbing pants for professionals. Unpublished masters thesis, Yonsei University. Seoul. Korea.

Jung, S. M., \& Chun, J. S. (2013). Professional climbers' demand for movement functionality in pants. The Research Journal of the Costume Culture, 21(2), 261-271. doi:10.7741/rjcc.2013.21.2.261

Kim, D.-H., \& Kim, K.-J. (2003). Changes of heart rate and blood lactate concentration during indoor climbing. Journal of Sport and Leisure Studies, 20(2), 955-967.

Kim, J. H. (2013). An analysis and subject on the market of fashion outdoor wear. Fashion Infor- mation and Technology, 10, 18-25.

Kim, J. S., Song, M. W., Ko, I. J., \& Park, J. H. (2015). Interactive artificial climbing structure for screen climbing. The Journal of Korean Institute of Next Generation Computing, 11(3), 73-86.

Kim, J.-Y., Lee, S.-K., Kim, S.-S., Kim, B.-K., \& Kim, M.-K. (2008). The analysis of left ventricular's functional and structural in rock-climber by computed tomography. Journal of Sport \& Leisure Studies, 32(2), 1069-1077.

Kim, W. J. (2016, August 16). '도쿄 올림픽 정식 종 목 채택' 스포츠클라이밍, 금메달 가능성은? [Sports climbing adopted as Tokyo Olympics official event, possibility of gold medal?]. Star News, Retrieved February 2, 2017, from http://star.mt.co.kr/stview. php?no=2016081616380895679

Lee, A.-L., Jeong, J.-R., \& Kim, H.-E. (2009). Research on the wearing condition of functional mountaineering garments. Journal of the Korean Society of Clothing and Textiles, 33(12), 19351940. doi:10.5850/JKSCT.2009.33.12.1935

Lee, D. Y., Cho, S. H., \& Park, H. B. (2014). Risk factors of past injuries among of the sports climbing athletes who participated in the national sports festival. The Korean Journal of Sports Medicine, 32(2), 85-91. doi:10.5763/kjsm.2014.32.2.85

Lee, E.-H. (2010). A study on the suitability of outdoor wear among female trekkers in their twenties and thirties. Journal of the Korean Society of Clothing and Textiles, 34(9), 1470-1478. doi:10.5850/ JKSCT.2010.34.9.1470

Lee, E.-Y., Heo, M.-H., Cha, K. S., \& Kim, D. H. (2016, January). Application of a character animation-based training system for sport climbing and its user evaluation. Extended abstracts of HCL Korea 2016, Jeongseon, Gangwon-do, 45-47.

Lee, J. H. (2016, August 4). 스포츠클라이밍, 2020년 도쿄올림픽 정식 종목 채택 [Sports climbing adopted 2020 Tokyo Olympic Games]. Outdoor news, Retrieved October 5, 2016, from http://www. outdoornews.co.kr/news/articleView.html?idxno= 
22396

Lee, M.-G., Lee, J.-E., \& Kang, C.-K. (2013). Effects of sports climbing club activity on physical fitness, falling injury-related variables, and cardiovascular function in middle-aged women. The Korea Journal of Sports Science, 22(3), 1235-1247.

Lee, Y. S., \& Eum, J. E. (2012). Consumer and supplier research on domestic women's sports riding wear. Journal of the Korean Society of Fashion Design, 12(4), 63-80.

Mermier, C. M., Janot, J. M., Parker, D. L., \& Swan, J. G. (2000). Physiological and anthropometric determinants of sport climbing performance. British Journal of Sports Medicine, 34(5), 359-366. doi: 10.1136/bjsm.34.5.359

Neuhof, A., Hennig, F. F., Schöffl, I., \& Schöffl, V. (2011). Injury risk evaluation in sport climbing. International Journal of Sports Medicine, 32(10), 794-800. doi:10.1055/s-0031-1279723

Outdoor Foundation. (2016). Outdoor participation report 2016. Outdoor foundation. Retrieved January 30, 2017, from http://www.outdoorfoundation.org/ pdf/ResearchParticipation2016.pdf

Park, S. B., Lee, K. D., Kim, K. H., Park, J. J., Jun, S. P., \& Ryu, W. H. (2015, October). 클라이밍 동작의 족저압력 분석을 통한 스포츠 클라이밍화 개발 [Development of footwear for sports climbing through analysis of foot pressure of climbing motion]. Proceedings of Fall Conference of the Ergonomics Society of Korea, Busan, 266-270.

Schöffl, V., Morrison, A., Schwarz, U., Schöffl, I., \& Küpper, T. (2010). Evaluation of injury and fatality risk in rock and ice climbing. Sports Medicine, 40(8), 657-679. doi:10.2165/11533690-0000 00000-00000

Schöffl, V., \& Winkelmann, H. P. (1999). Accident statistics at "indoor climbing walls". Sportverletz Sportschaden, 13(1), 14-16. doi:10.1055/s-2007993308

Seo, E. J., \& Chun, J. S. (2014). Demand for functional elements of sports climbing shirts. The Re- search Journal of the Costume Culture, 22(2), 198-208. doi:10.7741/rjcc.2014.22.2.198

Sheel, A. W. (2004). Physiology of sport rock climbing. British Journal of Sports Medicine, 38(3), 355-359. doi:10.1136/bjsm.2003.008169

Son, J. J. (2003). 생활체육: 스포츠 클라이밍 [Leisure sports: Sports climbing]. Sport Science, 84, 46-52.

Son, J.-J. (2007). Comparison of physical fitness, blood lactate concentration and heart rates $d u$ ring sport climbing by skill level of male high school sports climbing players. Unpublished masters thesis, Kyung Hee University. Seoul. Korea. Son, J. J., Kang, C. K., Jung, W. S. \& Lee, M. G. (2013a). Comparative analysis of body composition, cardiorespiratory function, and blood variables according to career of sports climbing club activity in middle-aged men. Exercise Science, 22(4), 351-362.

Son, J.-J., Kang, C.-K., Jung, W.-S., \& Lee, M.-G. (2013b). Effects of sports climbing club activity on physical fitness and falling injury-related variables in middle-aged men. The Korea Journal of Sports Science, 22(5), 1337-1350.

Sung, B. J. (2009). 올 가을에는 스포츠클라이밍을 즐 겨보자 [Let's do sports climbing in autumn]. The Korea Public Health Association, 건강생활 [Health and Life], 2009(Fall), 38-39. Retrieved from http:// www.kpha.or.kr/inc/CommDown.php?p_folder $=\mathrm{C}$ 030\&amp;file=\%2F201112\%2F09 3.pdf\&amp;fil e_name $=09 \_3 . p d f$

Watts, P., Newbury, V., \& Sulentic, J. (1996). Acute changes in handgrip strength, endurance, and blood lactate with sustained sport rock climbing. The Journal of Sports Medicine and Physical Fitness, 36(4), 255-260.

Wright, D. M., Royle, T. J., \& Marshall, T. (2001). Indoor rock climbing: Who gets injured? British Journal of Sports Medicine, 35(3), 181-185. doi: 10.1136/bjsm.35.3.181 